$<$ Back to results | 1 of 1

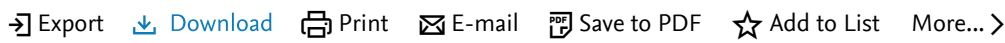

Full Text

Document type

Conference Paper

Source type

Conference Proceedings

ISBN

978-172811064-6

DOI

10.1109/ICCCE50029.2021.9467150

View more $\checkmark$

Proceedings of the 8th International Conference on Computer and Communication Engineering, ICCCE 2021 • Pages 110 - 114 • 22 June 2021 - Article number 9467150 - 8th International Conference on Computer and Communication Engineering, ICCCE 2021 • Kuala Lumpur • 22 June 2021 through 23 June 2021 • Code 171135

\section{Evaluation of Energy Harvesting for Smart Cane Application}

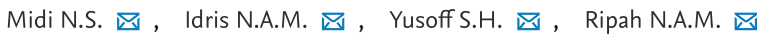

国 Save all to author list

International Islamic University Malaysia (IIUM), Department of Electrical and Computer Engineering, Kuala, Malaysia

Full text options $\vee$

Abstract

Author keywords

Indexed keywords

SciVal Topics

Abstract

Walking cane is a device used by disabled people to navigate themselves. In recent days, it is equipped with various sensors and functions and it is known as a smart cane. It is already available in the market. However, the smart cane is depending on the battery supply that has to be charged every now and then. In relation to that, this paper is focusing on evaluating energy harvesting for powering up a smart cane. This project evaluates possible energy harvesting considering the nature of usage which are outside, gripping motion, tapping motion of the cane itself. Here, an energy harvesting system was designed and attached to a walking stick and the energy generated was observed. The system consists of a combination of solar modules and piezoelectric modules. The solar modules were attached to the handle, whilst the piezoelectric modules were attached to the bottom of the cane. From there, an experimental evaluation was done by testing the cane in indoor and outdoor environment by subjects with different body profile. The result shows that higher power is generated during outdoor usage, and this shows that the solar modules contribute the most to the generated energy. On the other hand, the piezoelectric modules only contribute a small portion of the generated energy. However, this contribution is significantly important during the usage of the cane in indoor environment, where less sunlight is available. @ 2021 IEEE.

Author keywords

energy harvesting; piezoelectric; smart cane; solar
Cited by 0 documents

Inform me when this document is cited in Scopus:

Set citation alert >

\section{Related documents \\ Design of neurocane for blind community using loT device \\ Karkuzhali, S. , Mishra, A. , Ajay, M.S. (2020) 2020 International Conference on Computer Communication and Informatics, ICCCI 2020}

Object detection and sensory feedback techniques in building smart cane for the visually impaired: An overview

Asad, S. , Mooney, B., Ahmad, I. (2020) PervasiveHealth: Pervasive Computing Technologies for Healthcare

Smart Blind Stick for Visually Impaired People

Nguyen, H.Q. , Duong, A.H.L. , Vu, M.D. (2022) IFMBE Proceedings

View all related documents based on references

Find more related documents in Scopus based on:

Authors > Keywords >

Indexed keywords 
1 Sheth, R., Rajandekar, S., Laddha, S., Chaudhar, R.

Smart White Cane-An Elegant and Economic Walking Aid

(2014) American Journal of Engineering Research (AJER, 3 (10), pp. 84-89. Cited 21 times.

2 Satpute, R., Mansuri, M., Kulkarni, D., Sawant, A.

Smart Cane for Visually Impaired Person by Using Arduino

(2016) Imperial Journal of Interdisciplinary Research (IJIR, 2 (11), pp. 1420-1432. Cited 5

times.

3 Mithiles, K., Kabir, F., Roy, S.

Low Cost Smart Stick for Blind and Partially Sighted People

(2017) International Journal of Advanced Engineering and Management, 2 (3), pp. 65-

68. Cited 7 times.

4 Nada, A., Mashelly, S., Fakhr, M.A., Seddik, A.F.

Effective Fast Response Smart Stick for Blind People

(2015) Second International Conference on Advances in Bio-Informatics and

Environmental Engineering, pp. 1-7. Cited 14 times.

5 Dey, N., Paul, A., Ghosh, P., Mukherjee, C., De, R., Dey, S.

Ultrasonic Sensor Based Smart Blind Stick

(2018) Proceedings of the 2018 International Conference on Current Trends towards

Converging Technologies, ICCTCT 2018, art. no. 8551067. Cited 15 times.

http://ieeexplore.ieee.org/xpl/mostRecentlssue.jsp?punumber=8536362

ISBN: 978-153863701-2

doi: $10.1109 /$ /СCTCT.2018.8551067

View at Publisher

6 Loganathan, N., Lakshmi, K., Chandrasekaran, N., Cibisakaravarthi, S.R., Priyanga,

R.H., Varthini, K.H.

Smart Stick for Blind People

(2020) 2020 6th International Conference on Advanced Computing and Communication Systems, ICACCS 2020, art. no. 9074374, pp. 65-67. Cited 3 times.

http://ieeexplore.ieee.org/xpl/mostRecentlssue.jsp? punumber=9058619

ISBN: 978-172815197-7

doi: $10.1109 /$ ICACCS48705.2020.9074374

View at Publisher

7 Hussain, M.A., Ullah, M.G., Fareed, A., Sohail, B.

The Smartcane for Blind People An Electronically Smart Stick to Aid Mobility

(2016) International Journal of Computer Science and Information Security, 14 (4), pp.

276-285. Cited 3 times.

8 Pauline Jothi Kiruba, G.J., Mohan Kumar, T.C., Kavithrashree, S., Ajith Kumar, G. Smart Electronic Walking Stick for Blind People

(2018) International Journal of Advanced Research in Electrical, Electronics and Instrumentation Engineering, 7 (3), pp. 1194-1200.

9 Mohindru, R., Jain, P., Khosla, N.

Smart Walking Stick for Visually Impaired

(2020) International Research Journal of Engineering and Technology (IRJET, 7 (1), pp.

1809-1812. 
10 Singh, V., Paul, R., Mehra, D., Gupta, A.G., Sharma, V., Jain, S., Agarwal, C., (...), Manocha, D.

'Smart' Cane for the Visually Impaired: Design and Controlled Field Testing of an Affordable Obstacle Detection System

(2010). Cited 3 times.

11 Hapsari, G.I., Mutiara, G.A., Kusumah, D.T.

Smart cane location guide for blind using GPS

(2017) 2017 5th International Conference on Information and Communication Technology, IColC7 2017, art. no. 8074697. Cited 6 times.

ISBN: 978-150904912-7

doi: 10.1109/IColCT.2017.8074697

View at Publisher

12 Retnowati, Y., Budi, A.H.S.

Smart Cane Using ESPectro with GPS Tracking System (Open Access)

(2018) IOP Conference Series: Materials Science and Engineering, 384 (1), art. no.

012054. Cited 2 times.

http://www.iop.org/EJ/journal/mse

doi: $10.1088 / 1757-899 \times / 384 / 1 / 012054$

View at Publisher

13 Castillo Guerrero, J., Quezada-V, C., Chacon-Troya, D.

Design and Implementation of an Intelligent Cane, with Proximity Sensors, GPS Localization and GSM Feedback

(2018) Canadian Conference on Electrical and Computer Engineering, 2018-May, art. no. 8447741. Cited 6 times.

http://ieeexplore.ieee.org/xpl/conhome.jsp?punumber=1000225

ISBN: 978-153862410-4

doi: $10.1109 / C C E C E .2018 .8447741$

View at Publisher

14 Yamamoto, K., Suganuma, K., Sugimori, D., Murotani, M., Iwamoto, T., Matsumoto, M.

Walking support system with robust image matching for users with visual impairment

(2011) Conference Proceedings - IEEE International Conference on Systems, Man and Cybernetics, art. no. 6083821, pp. 1100-1105. Cited 5 times.

ISBN: 978-145770652-3

doi: 10.1109/ICSMC.2011.6083821

View at Publisher

15 Krishnan, A., Deepakraj, G., Nishanth, N., Anandkumar, K.M.

Autonomous walking stick for the blind using echolocation and image processing

(2016) Proceedings of the 2016 2nd International Conference on Contemporary Computing and Informatics, IC3/ 2016, art. no. 7917927, pp. 13-16. Cited 11 times. ISBN: 978-150905255-4

doi: $10.1109 /$ IC3I.2016.7917927

View at Publisher

(C) Copyright 2021 Elsevier B.V., All rights reserved.

About Scopus

What is Scopus

Content coverage

Scopus blog

Scopus API

Privacy matters
Language

日本語に切り替える

切换到简体中文

切換到繁體中文

Русский язык
Customer Service

Help

Contact us 
